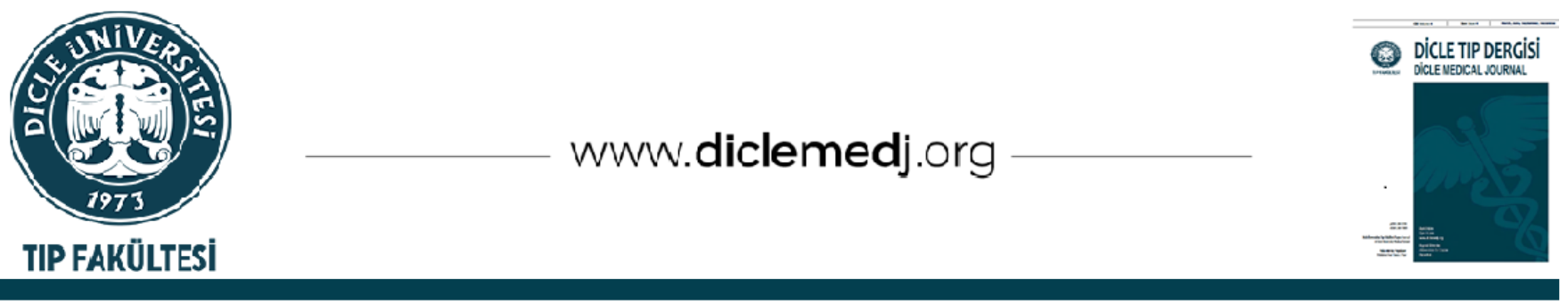

Original Article / Özgün Araştırma

\title{
Heterotopic gastric mucosa (inlet patch): Endoscopic prevalence and association with supraesophageal and upper esophageal symptoms
}

\author{
Remzi Beștaş ${ }^{\mathrm{D}} \mathbf{1}$, Nazım Ekin ${ }^{\mathrm{D}} 2$ \\ 1 Memorial Dicle Hospital, Gastroenterology Department, Diyarbakır, Turkey \\ 2 Health Sciences University Diyarbakır Gazi Yaşargil Training and Research Hospital, Gastroenterology Department. Diyarbakır, Turkey \\ Received: 05.08.2021; Revised: 23.08.2021; Accepted: 23.08.2021
}

\begin{abstract}
Objective: To determine the frequency, demographic and clinical features of the heterotopic gastric mucosa (inlet patch).

Methods: This retrospective study involves 244 patients who applied to the gastroenterology outpatient clinic with different symptoms between September 2016 and December 2019, and who were diagnosed with inlet patch in elective esophagogastroduodenoscopy. All endoscopic procedures were performed by the same clinical endoscopist. All medical records of patients including demographic and clinical features and endoscopy findings were reviewed.

Results: Considering 2823 patients who underwent elective esophagogastroduodenoscopy in the same study period, inlet patch was detected in 224 (8.6\%). The number of male patients was $138(56.6 \%)$ and there was no statistical difference between the two genders. The mean age of the patients was $37.73 \pm 13.01$ years. Single lesion was detected in $204(83.6 \%)$ patients. The size of the largest lesion was $4.5 \mathrm{~cm}$ and the smallest lesion was $0.3 \mathrm{~cm}$. All of the lesions were in the proximal esophagus. 54 patients $(22.1 \%)$ had at least one supraesophageal or upper esophageal symptom. The most common symptom was globus sensation (64.8\%). Patients with large lesions were more likely to experience symptoms (28.2\% vs. $13.7 \%$, p=0.008).

Conclusion: Careful examination of the proximal esophagus may increase the chance of detecting inlet patch and may explain persistent symptoms in patients without a specific cause. Further understanding of the clinical significance of the disease may also prevent unnecessary diagnostic interventions.
\end{abstract}

Keywords: İnlet patch, Heterotopic gastric mucosa, Prevalence, Globus sensation, Endoscopy

DOI: $10.5798 /$ dicletip.988062

Correspondence / Yazıșma Adresi: Remzi Beștaş, Memorial Dicle Hospital, Department of Gastroenterology. Diyarbakır, Turkey e-mail: bestasr@gmail.com 


\section{Heterotopik mide mukozası (inlet patch): Endoskopik prevalansı ile supraözofageal ve üst özofageal semptomlar ile ilişkisi}

$\ddot{0} \mathbf{z}$

Amaç: Heterotopik mide mukozasının (Inlet patch) sıklığını, demografik ve klinik özelliklerini belirlemek amaçlandı.

Yöntemler: Gastroenteroloji polikliniğine Eylül 2016 ve Aralık 2019 tarihleri arasında değişik semptomlar ile başvuran, endoskopi endikasyonu konulan ve elektif olarak tek endoskopist tarafindan özofagogastroduodenoskopi yapılan 2823 hasta çalışmaya dahil edildi. İnlet patch tespit edilen 244 hastanın verileri analiz edildi. Hastaların demografik ve klinik özellikleri ile lezyonun özellikleri kaydedildi.

Bulgular: Bu çalışmada elektif özofagogastroduodenoskopi yapılan 2823 hasta göz önüne alındığında, inlet patch hastaların 224'ünde $(\% 8,6)$ tespit edildi. İnlet patch tespit edilen hastaların \%56,6'sı erkek olup iki cinsiyet arasında istatistiksel fark yoktu. Hastaların yaş ortalaması $37.73 \pm 13.01$ yıl idi. Hastaların \%83,6'sında sadece bir lezyon vardı. En büyük lezyonun boyutu $4.5 \mathrm{~cm}$, en küçük lezyon ise $0.3 \mathrm{~cm}$ idi. Lezyonların hepsi proksimal özefagusta yerleșikti. Hastaların $54(\% 22,1)$ 'ünde supraözofajial ve üst özofajial semptomlardan en az biri mevcuttu. Bu semptomlardan en sık görüleni de globus hissi $(\% 64,8)$ idi. Lezyonu büyük olan hastalarda semptom görülme ihtimali daha yüksek idi (\%28,2'ye \%13,7, p=0.008).

Sonuç: Proksimal özofagusun dikkatli incelenmesi inlet patchin tespit etme şansını artırabilir ve bazı hastalarda belirli bir nedeni olmayan inatçı semptomları açıklayabilir. Hastalığının klinik öneminin daha fazla anlaşılması, gereksiz tanısal girișimleri de engelleyebilir.

Anahtar kelimeler: İnlet patch, Heterotopik mide mukozası, Prevalans, Globus hissi, Endoskopi.

\section{INTRODUCTION}

Heterotopic gastric mucosa (HGM), which is also called inlet patch (IP) is characterized by congenital existence of salmon-color gastric columnar epithelial islands in the cervical esophagus. These patch-shaped islets, observed just below the upper esophageal sphincter, vary in diameter from a few millimeters to $4.5-5 \mathrm{~cm}^{1-}$ 3 . An inlet patch may be slightly convex, flat, or concave, and these ectopic mucous islands, separated from normal mucous by sharp borders, can be seen as a single piece or multiple pieces. The incidence of endoscopically diagnosed inlet patch has a large variation ${ }^{4-6}$. Wide variation in this incidence may be related to the anatomical localization of inlet patches and insufficient examination of the proximal esophagus by endoscopists. The increasing awareness of endoscopists about the presence of HGM and identification of its association with some symptoms increased the rate of endoscopic diagnosis of this lesion7. This lesion, the clinical significance of which is not exactly known yet, may cause sticking sensation, foreign body sensation and/or burning complaints in the proximal part of the esophagus. This study evaluates the incidence of inlet patch, and its association with age, gender and symptoms in the esophagogastroduodenoscopy (EGD) procedures performed by a single endoscopist under sedation, during which the proximal esophagus was carefully examined.

\section{METHODS}

This retrospective study involves 244 patients diagnosed with inlet patch from 2823 patients who applied to the gastroenterology outpatient clinic with different symptoms between September 2016 and December 2019, signed a written consent form, and underwent elective endoscopy. Patients whose endoscopic data were not clear were excluded from the study. Following full sedation under the supervision of an anesthesiologist after at least 8 hours of fasting, the patients underwent upper endoscopy performed by a single endoscopist. 
Proximal esophagus was examined in detail during all endoscopy procedures. Inlet patch (HGM) was defined as patch-shaped lesions covered with salmon-red mucosa, the boundaries of which can be distinguished from the pearl gray esophageal mucosa (Figure 1a-b). Demographic data of 244 patients diagnosed with inlet patch were recorded. The size of each inlet patch was determined by the top opening of the fully open biopsy forceps. The size, number and localization of the lesions were recorded. Inlet patch lesions were divided numerically into two groups, as single and multiple. Then, the lesions were distributed according to age and gender. Globus sensation, hoarseness, voice thickening, sore throat, cough, dysphagia, and odynophagia were considered as supraesophageal and upper esophageal symptoms. The presence of these symptoms and their association with the number and size of inlet patches were evaluated. This study was approved by the Clinical Research Ethics Committee at Health Sciences University Diyarbakır Gazi Yaşargil Training and Research Hospital (15.01.2021/621).

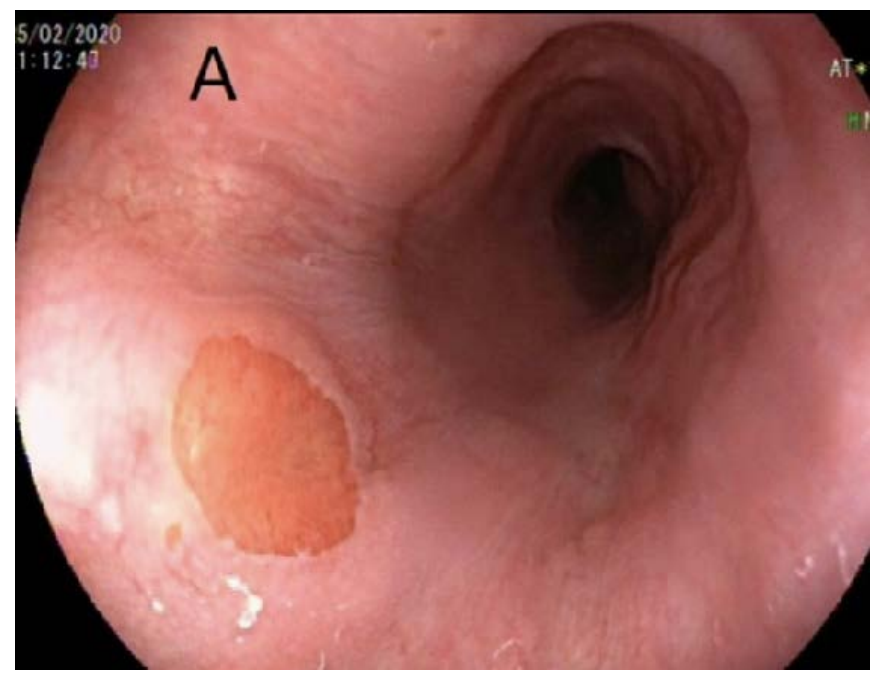

Figure 1a: Endoscopic images of heterotopic gastric mucosa of the proximal esophagus. Flat, round inlet patches in white light endoscopy vs

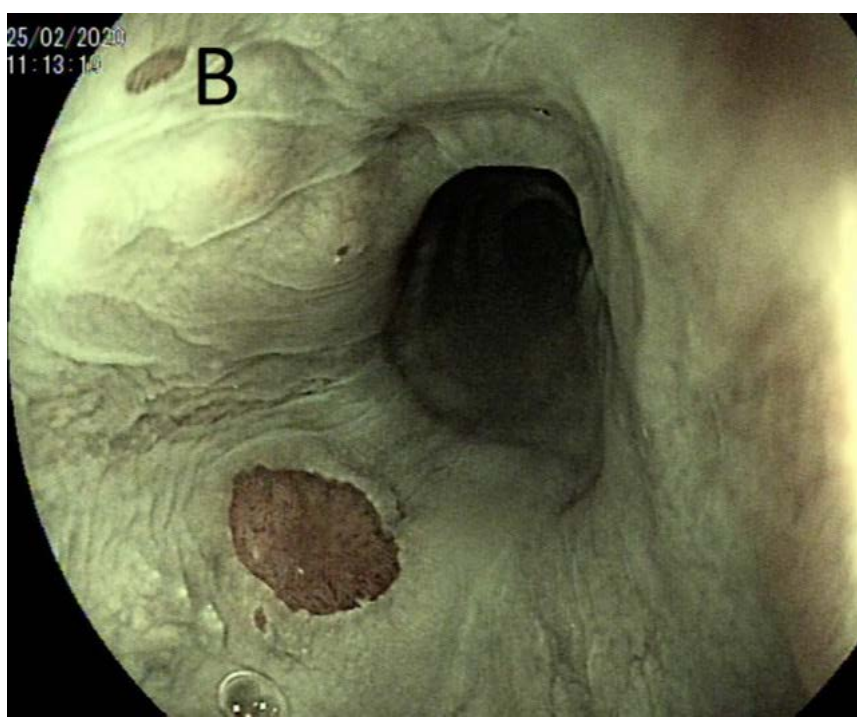

Figure 1b: optical chromoendoscopy (narrow band imaging), in a middle age man.

\section{Statistical Analysis}

All statistical analyzes were performed by using statistical Package (SPSS) 21.0 software. For the significance of the difference between the two groups, the categorical variables were compared by using the Pearson's chi-squared test or Fisher's exact test, and continuous variables were compared by using Student's $t$ test. Two-way values $\mathrm{p}<0.05$ were considered statistically significant.

\section{RESULTS}

In our study, IP was endoscopically detected in $244(8.64 \%)$ of 2843 patients who underwent EGD. The mean age of patients diagnosed with IP was $37.73 \pm 13.01 .106(43.4 \%)$ of the patients were female and $138(56.6 \%)$ were male. All of the IP lesions observed in the patients were located in the proximal esophagus. Single lesion was detected in 204 $(83.6 \%)$ patients and multiple lesions in 40 (16.4\%). The smallest lesion was $0.3 \mathrm{~cm}$, while the largest lesion was $4.5 \mathrm{~cm}$. While no supraesophageal or upper esophageal symptom was found in 190 (77.9\%) of the patients, 54 $(22.1 \%)$ of the patients had at least one of the supraesophageal and upper esophageal symptoms. Globus sensation (64.8\%) was the 
most common symptom followed by dysphagia (12.9\%), and cough (11.1\%). Age did not have a significant relation with the symptoms or the number and size of the lesion ( $p>0.05$ ). However, the patients with large lesions were more likely to experience symptoms (28.2\% vs. $13.7 \%, p=0.008)$. Demographic data of the patients and distribution of symptoms are given in the table 1 and table 2.

Table I: Demographic characteristics of patients.

\begin{tabular}{|lc|}
\hline Variables & \\
Age, year, mean \pm SD (min-max) & $37.73 \pm 13.01(16-77)$ \\
Female, $\mathbf{n}(\%)$ & $106(43.4 \%)$ \\
Male, $\mathbf{n}(\%)$ & $138(56.6 \%)$ \\
Number of pathces, $\mathbf{n}(\%)$ & \\
$<\mathbf{1}$ & $204(83.6 \%)$ \\
$>\mathbf{1}$ & $40(16.4 \%)$ \\
\hline
\end{tabular}

SD; standart deviation, n;number

Table II: Clinical features of patients.

\begin{tabular}{|c|c|}
\hline $\begin{array}{l}\text { Supra esophageal/ upper esophageal } \\
\text { symptoms, n (\%) }\end{array}$ & $54(22.1 \%)$ \\
\hline Globus sensation & $35(64.8 \%)$ \\
\hline Hoarseness & $3(5.5 \%)$ \\
\hline Dysphagia & $7(12.9 \%)$ \\
\hline Sore throat & 0 \\
\hline Chronic cough & $5(11.1 \%)$ \\
\hline Odynophagia & $3(5.5 \%)$ \\
\hline
\end{tabular}

Ectopic gastric mucosa may appear anywhere along the gastrointestinal tract. It was first defined by Schmidt in 1805 and it is usually located in the postcricoid area of the esophagus or just below the upper esophageal sphincter and it is considered to be a congenital anomaly. The lesion is more common when the endoscope shaft is pulled by the endoscopist very slowly from the proximal esophagus ${ }^{6,8}$. The incidence of these lesions, which are frequently ignored by endoscopists, has been reported in a wide range of $1 \%$ to $13.8 \%{ }^{3,5-7}$. In this study, the incidence of inlet patch was found to be $8.64 \%$. The mean age of the patients was $37.73 \pm 13.01$, and it was more common in male patients with $56.6 \%$. The incidence rate of inlet patch in our study was higher than many reported studies. Due to the fact that all cases were performed by a single endoscopist, and the proximal esophagus was examined in detail, a higher rate was found in our study compared to many other reported studies. While inlet patch is seen at any age, it is typically seen in fifties ${ }^{9}$. Our study found that it is also seen at younger ages. With detailed examination of the proximal esophagus, inlet patch diagnostic efficiency can be increased. In addition, the use of NBI can increase the frequency and accuracy of diagnosis $^{10-12}$. In our own experience, we have seen that the most important event that increases the frequency of inlet patch diagnosis is a detailed examination of the esophagus proximal.

The clinical significance of inlet patch (IP) is not known much. Inlet patch, which is mostly asymptomatic, causes supraesophageal and upper esophageal symptoms, but it is usually detected in endoscopic examinations carried out due to other gastrointestinal complaints. However, inlet patch may also appear with more serious medical problems such as pain, dysphagia, ulcer, bleeding, perforation or esophageal web ${ }^{13,14}$. While there are publications supporting the increase in the severity of symptoms with the size of the lesion 15,16 the relationship between acid secretion and inlet patch-related symptoms remains uncertain. Studies suggest that only a small proportion of symptomatic patients had acid secretion from inlet patch ${ }^{17,18}$. Patients who are symptomatic typically have laryngopharyngeal symptoms such as globus pharyngeus, sore throat, hoarseness, chronic cough, throat clearing, and dysphagia, and these symptoms are thought to occur due to irritation of the airways and vocal cords due to acid 
secretion ${ }^{19,20}$. Macha et al. ${ }^{21}$ showed that children with IP had a higher rate of respiratory symptoms compared to the control group. Poyrazoglu et al. ${ }^{15}$ also reported a higher incidence of dysphagia in adults with IP. Another study shows that the frequency of upper esophageal or laryngopharyngeal symptoms did not differ between the case group and control group 55 (22.1\%) of our patients with inlet patch had at least one of the supraesophageal and upper esophageal symptoms. None of our patients had severe complications. Conducted studies reported the frequency of upper esophagus and supraesophageal symptoms in inlet patch patients at rates ranging from below $20 \%$ to $70 \%{ }^{22}$. The reason for the fact that this ratio is slightly lower in our study may be due to the fact that our study was retrospective and these symptoms were not adequately questioned. No relation was found among the frequency of symptoms, the number of lesions and the age of patients. In line with the above-mentioned publications, the frequency of symptoms was significantly higher in patients with lesions greater than $1 \mathrm{~cm}$ (p: 0.008).

While IP is typically seen as a single lesion, it can also be seen as multiple lesions ${ }^{20}$. In our study, a single lesion was found in 204 (83.6\%) of the IP cases, while $40(16.4 \%)$ of the cases showed 2 or more lesions in accordance with the literature, The size of the lesions in the inlet patch can vary from a few millimeters to 4.5-5 $\mathrm{cm}^{1,5}$. In our study, while the size of lesion was less than $1 \mathrm{~cm}$ in 102 (41.8\%) cases, it was larger than $1 \mathrm{~cm}$ in 142 (58.2\%) patients, with the largest one being $4.5 \mathrm{~cm}$.

Strictures and webs are treated with serial dilatation but should include biopsy to rule out malignancy5,23 Overall, significant histological non-malignant changes or malignancies in HGMPE are extremely rare. Neoplastic transformations have only been reported in the adult population 22,24 . Since the first case reported by Carrie et al ${ }^{25}$ in 1950 there have only been 43 cases of adenocarcinoma ${ }^{26-28}$ in association with HGMPE reported in the literatüre to date. Based on two studies, it can be estimated that the incidence of malignancies among patients with HGMPE ranges between 0 and $1.56 \%{ }^{29}$.

There is no standardized treatment strategy for inlet patch. Treatment is not required for asymptomatic patients. For symptomatic patients, H2-receptor antagonists or proton pump inhibitors can be used. Dilatation may be performed for strictures and webs. Furthermore, laser or radiofrequency ablation of inlet patches has been shown to relieve globus and has been used to successfully treat inlet patch dysplasia although its routine use in this context has not been determined 8,20,30.

In conclusion, the incidence of this disease, which is usually diagnosed incidentally, varies greatly. Careful examination of the proximal esophagus contributes to a significant increase in the diagnosis rate of inlet patch. With the diagnosis of inlet pach, the etiology of symptoms such as sore throat, globus sensation and dysphagia, which have become uncomfortable and chronic in some patients, can be detected and this may help to prevent many examinations in such patients. Acid secretion blockers can relieve symptoms. Inlet patch will become more clear with the increase in the diagnosis rate of this typically-overlooked disease and the publications on the subject.

Ethics Committee Approval: This study was approved by the Clinical Research Ethics Committee at Health Sciences University Diyarbakır Gazi Yaşargil Training and Research Hospital (15.01.2021/621).

Financial support and sponsorship: There is no financial support in this study.

Conflicts of interest: There are no conflicts of interest. 


\section{REFERENCES}

1. Jabbarı M, Goresky JA, Lough J, et al. The Inlet patch: heterotopic gastric mucosa in the upper esophagus. Gastroenterology. 1985; 89:352-6.

2. Tang P, McKinley MJ, Sporrer M, et al. Prevalence, Histologic Type and Association With Esophagitis, Barrett Esophagus, and Antritis. Arch Pathol Lab Med. 2004; 128: 444-7.

3. Chong HV. Clinical significance of heterotopic gastric mucosal patch of the proximal esophagus. World J Gastroenterol. 2013; 19: 331-8.

4. Chung CS, Lin CK, Liang CC, et al. Intentional examination of esophagus by narrow-band imaging endoscopy increases detection rate of cervical inlet patch. Dis Esophagus. 2015; 28: 666-72.

5. Akbayir N, Alkim C, Erdem L. Heterotopic gastric mucosa in the cervical esophagus (inlet patch): endoscopic prevalence, histological and clinical characteristics. Journal of Gastroenterology and Hepatology. 2004; 19: 891-6.

6. Ohara M. Incidence of heteroptopic gastric mucosa in the upper esophagus in first time narrow banding image endoscopy of consecutive 900 patients. Gastrointest Endosc. 2010; 71: 316-7.

7. Maconi G, Pace F, Vago L, et al. Prevalence and clinical features of heterotopic gastric mucosa in the upper oesophagus (inlet patch). European Journal of Gastroenterology and Hepatology. 2000; 12: 745-9.

8. Behrens C, Peggy PWY. Esophageal Inlet Patch. Radiology Research and Practice. 2011; 1-3.

9. Savaş N. Heterotopik Gastrik Mukoza (Gastrik İnlet Patch) Güncel gastroenteroloji. 2014; 18: 3269.

10. Kawada K, Kawano T, Sugimoto T, et al. Case of Superficial Cancer Located at the Pharyngoesophageal Junction Which Was Dissected by Endoscopic Laryngopharyngeal Surgery Combined with Endoscopic Submucosal Dissection. Case Rep Otolaryngol. 2017; 2017: 1-7.

11. Yoshida $T$, Inoue $H$, Usui $S$, et al. Narrow-band imaging system with magnifying endoscopy for superficial esophageal lesions. Gastrointest Endosc. 2004; 59: 288-95.
12. Inoue $\mathrm{H}$, Kaga $\mathrm{M}$, Ikeda $\mathrm{H}$, et al. Magnification endoscopy in esophageal squamous cell carcinoma: a review of the intrapapillary capillary loop classification. Ann Gastroenterol. 2015; 28: 41-8.

13. Raine $\mathrm{CH}$. Ectopic gastric mucosa in the upper esophagus as a cause of dysphagia. Ann Otol Rhinol Laryngol. 1983; 92: 65-6.

14. Sanchez PA, Hernando F, Diez VL, et al. Heterotopic gastric mucosa in the upper esophagus ("inlet patch"): a rare cause of esophageal perforation. Am J Gastroenterol. 1999; 94: 3047-50.

15. Poyrazoglu OK, Bahcecioglu IH, Dagli AF, et al. Heterotopic gastric mucosa (inlet patch): endoscopic prevalence, histopathological, demographical and clinical characteristics. Int J Clin Pract. 2009; 63: 287-91.

16. Georges A, Coopman S, Rebeuh J, et al. Inlet patch: clinical presentation and outcome in children. J Pediatr Gastroenterol Nutr. 2011; 52: 419-23.

17. Kim EA, Kang DH, Cho HS, et al. Acid secretion from a heterotopic gastric mucosa in the upper esophagus demonstrated by dual probe 24-hour ambulatory $\mathrm{pH}$ monitoring. Korean J Intern Med. 2001; 16: 14-17.

18. Feurle GE, Helmstaedter V, Buehring A, et al. Distinct immunohistochemical findings in columnarepithelium of esophageal inlet patch and of Barrett' s esophagus. Dig Dis Sci. 1990; 35: 86-92.

19. Silvers WS, Levine JS, Poole JA, et al. Inlet patch of gastric mucosa in upper esophagus causing chronic cough and vocal cord dysfunction. Annals of Allergy, Asthma and Immunology. 2006; 96: 112-5.

20. Ford CN. Evaluation and management of laryngopharyngeal reflux. JAMA. 2005; 294: 153440.

21. Macha S, Reddy S, Rabah R, et al. Inlet patch: heterotopic gastric mucosa-another contributor to supraesophageal symptoms. J Pediatr. 2005; 147: 379-82.

22. Chong VH. Heterotopic gastric mucosal patch of the proximal esophagus. In: Pascu 0 , editor. Gastrointestinal Endoscopy. Croatia: InTech Publishing. 2011: 125-48. 
23. Von Rahden BHA, Stein HJ, Becker $\mathrm{K}$, et al. Heterotopic gastric mucosa of the esophagus: literature-review and proposal of a clinicopathologic classification. American Journal of Gastroenterology. 2004; 99: 543-51.

24. Bataller R, Bordas JM, Ordi J, et al. Upper gastrointestinal bleeding: a complication of "inlet patch mucosa" in the upper esophagus. Endoscopy. 1995; 27: 282.

25. Carrie A. Adenocarcinoma of the upper end of the oesophagus arising from ectopic gastric epithelium. Br J Surg. 1950; 37: 474.

26. Yoshida T, Shimizu Y, Kato M. Image of the month. Use of magnifying endoscopy to identify early esophageal adenocarcinoma in ectopic gastric mucosa of the cervical esophagus. Clin Gastroenterol Hepatol. 2010; 8: 91-3.
27. Komori S, Osada S, Tanaka Y, et al. A case of esophageal adenocarcinoma arising from the ectopic gastric mucosa in the thoracic esophagus. Rare Tumors. 2010; 2: 5.

28. Isozaki $\mathrm{Y}$, Maruyama $\mathrm{T}$, Takeshita $\mathrm{N}$, et al. Primary esophageal adenocarcinoma arising from heterotopic gastric mucosa: report of a case. Surg Today. 2013; 43: 446-55.

29. Neumann WL, Luján GM, Genta RM. Gastric heterotopia in the proximal oesophagus ("inlet patch"): Association with adenocarcinomas arising in Barrett mucosa. Dig Liver Dis. 2012; 44: 292-6.

30. Siboni S, Iasi G, Rausa E, et al. Lymphangioma of the cervical esophagus associated with an inlet patch. Eur Surg. 2012; 44: 413-5. 